\title{
The Personal Writings of Politicians
}

\section{Neal Blewett}

Some years ago, in my essay 'No Secret Selves?', I attempted to develop a typology for the personal writings of politicians. I have since tried to refine that typology, though I still remain unhappy with the nomenclature. I would now suggest a fivefold typology as follows: (1) personalised policy essay; (2) political autobiography; (3) political memoir; (4) politician's autobiography; and (5) political diary. As references in this workshop suggest that some of you have read that essay, I will spend little time on those categories that have remained unchanged and will concentrate on the refinements and more particularly on the category of the political diary.

The 'personalised policy essay' is an essay on a particular subject interlaced with personal experience and personal attitudes. A typical example is Paul Keating's philosophy of regional relations, Engagement: Australia Faces the Asia-Pacific (2000). Here is an account of a particular policy issue or set of policy issues; running through it are elements of Keating's own experience and Keating's personal comments and reflections. Another rather more stolid example is former Aboriginal Affairs Minister Robert Tickner's Taking a Stand: Land rights to reconciliation (2001), which examines Aboriginal policies from the perspective of the minister's own experiences.

The Political Autobiography is different from the Personalised Policy Essay in that it tries to comprehend the whole political life, rather than deal with a segment or an area of policy, however personalised. The Political Autobiography is focused overwhelmingly on the political life of the author with little in the way of personal introspection - here the public, not the private, life is on display. The reader finds out little about the politician's private life and the presentation usually aims to enhance the role of the author in the politics of his or her day.

An easy way of deciding whether you have a Political Autobiography in your hands is to see how rapidly the writer dispenses with his pre-political life. For instance, in The Hawke Memoirs (1994), a typical Political Autobiography some 600 pages long, Hawke is at the ACTU by page thirty. Peter Walsh, in Confessions of a Failed Finance Minister, dispatches the first thirty-eight years of his life in fourteen pages. Graham Richardson, in Whatever It Takes, starts counting the numbers in the very first chapter. Emphasis is very much on the political.

What I have clumsily called the 'politician's autobiography' is that kind of autobiography in which the author seeks not only to present his political life as thoroughly as in a 'political autobiography' but also grapples with their personal 
life, their pre-political life, their time after politics (in some cases) and to other interests outside the purely political. The politician's autobiography is usually a more introspective book than the political autobiography.

The classic Australian politician's autobiography of recent years is Bill Hayden's, Hayden: an Autobiography (1996). As I wrote elsewhere, 'at its worst the reader feels he is beside the psychotherapist's couch, at its best there is a raw, unflinching honesty about the book, about his personal life as well as his political life'.

I include the 'political memoir' out of deference to my colleague, John Button. Button has apparently skipped across life and politics so disarmingly — 'dodging raindrops' indeed - that he is too elusive to categorise. So I surrender to his own definition of his book, As It Happened (1998), which he describes as 'a memoir rather than an autobiography'. In Button's words, talking particularly about the political side, the political memoir, 'is not the full bottle ... it lacks the historian's discipline of poring over archives [providing] an account that seems to include everything'. The political aspect of the political memoir lacks the authority and comprehensiveness of a political autobiography or a politician's autobiography. There is no sense that armies of research students have been mobilised as they were for Hawke's book and, I suspect, for Hayden's, to provide the factual material and do the research to back up their claims. The political memoir is much more lightly done.

Moreover, in relation to the private side, Button himself admits that his political memoir omits 'things in my life ... which in different degrees have been more important than anything else in my life'. Thus, on the personal side, the political memoir is more lightweight than the politician's autobiography as it is more lightweight on the political side than the political autobiography. Skipping lightly across events therefore makes the political memoir the most elegant of these forms. Robert Menzies' Afternoon Light (1967) is a classic and elegiac example of the political memoir.

The 'political diary' is a distinct form of writing by a politician. It is usually as relentlessly political, often obsessively so, as the political autobiography. Most political diarists concentrate very much on the detail of the political life. Indeed, if you think of the classic modern examples - Richard Crossman (1975-77), Castle (1980), Howson (1984), Tony Benn (1987-1992), and even my own work - there is very little in any of these books about the personal lives of the writers. The diaries of all these politicians include fleeting references to their private lives but remain overwhelmingly political. Alan Clark (1993-2002) comes to mind as a possible exception - his enthusiastic accounts of his extra-political activities are compelling but, then, Clark is sui generis among contemporary political diarists. 
The political diary is usually aimed at political junkies. It tends to be dense with material, often in a pretty undigested form. There is not much selectivity, often for very good reasons, and is often, as a result, rather turgid.

The political diary is usually written by a member of the second eleven, or at least the lower half of the first eleven, that is by people who have the time to observe and to write their observations down. One review of my diary suggested I was 'an interested bystander', which is partly the point I am making. Another said that I was 'an observant fly on the Cabinet wall'. One of my colleagues suggested, tersely, if you substituted 'blowfly' for 'fly', you would be closer to the mark.

One should not underrate the advantages of the political diary. One great advantage is that it has an immediacy that most of the other forms of political writing lack, particularly if they are kept, as mine was, on a daily basis. As a result of this immediacy you learn about events before they collect the mythology that transforms them. I will give one example, 24 February 1992, the encounter between Paul Keating and Queen Elizabeth II, around which a vast mythology has accreted. This is simply my view that night of what happened.

There was a gathering of the political elite in the Great Hall of the Parliament to meet the Queen. There was also rather unseemly pressure, indeed a lot of pushing from Labor republicans - or rather from their wives - to be introduced to the Queen. Keating was much more dignified, relaxed and assured than he was with Bush, striking a restrained note of independence in his speech and guiding the Queen with aplomb through the milling hordes.

His guiding of the Queen through the throng became, in the British tabloids, 'The Lizard of Oz mauls our Queen'. There is something to be said for getting a record of events before they are subject to hyperbole.

Most autobiographical writing by politicians is dismayingly dogmatic - in part because they possess the great advantage of hindsight. You do not have that gift with a daily diary. On the eve of the 1993 election I wrote:

Of all the elections I have been involved in, this one I have found the most difficult to read. My instinct tells me we will lose: ten years and one million unemployed are a coincidence we can hardly survive. But my head and the polls suggest we may well win. This dilemma arises, I suspect, because I cannot factor in the effect of our own scare campaign. Are there, in total, enough groups out there sufficiently antagonised by one or more of the Hewson horrors to give us a slim majority? Tomorrow will tell. (Blewett 1999)

In political diaries the future is unknown, outcomes uncertain. In Hawke's autobiography, by contrast, we would find something like this: 'As always I accurately predicted the outcome'; or, in Hayden's writing, something like this: 
'Though convulsed by doubts I believed we would win'. Uncertainty is a characteristic of the political diary.

Moreover, in a political diary, not only is there uncertainty but the writer can get things plain wrong. For six years I have suffered ridicule for the last paragraph in A Cabinet Diary. On the evening of the election I wrote:

Keating claimed victory in a euphoric and apparently unprepared speech. 'This is the sweetest victory of all' And so it is. With luck it has opened the nineties to Labor and all the tough decisions of the last few years will now bring their rewards ... Tomorrow belongs to us. (Blewett 1999)

There are constraints on writing and publishing political diaries, particularly those by ministers. These constraints should be seen in the light of the two golden commandments for diarists:

1. thou shalt not alter entries as a result of hindsight; and

2. thou shalt not bowdlerise or soften the original entries.

If one wants to be a decent diarist these seem to me to be sacred commands.

As with all commandments these encounter difficulties in the real world. The first of these is that unlike political autobiographies, politician's autobiographies or political memoirs, where politicians seem to be able to discuss debates in cabinet without any serious concerns - look, for example, at Hawke and Peter Walsh - the political diary is seen differently, as somehow subversive, more dangerous than other kinds of political writing.

Censorship has been invoked against political diaries in the latter part of the twentieth century. Crossman (1975-77) had to fight a court battle to get his diaries published. I had the following warning shot across my bow when I indicated to the Department of the Prime Minister and Cabinet what I intended to do. The letter from the Secretary began politely enough but changed tone in the second paragraph:

At the outset I should make it clear that you should rely on your own legal advice in considering the legal risks that may be associated with publication. Whether any legal action, criminal or civil, is initiated would be entirely a matter for the Commonwealth government and relevant authorities. The comments I make in this letter should not be taken as any indication, let alone commitment, that legal remedies may not be pursued.

He pointed out how, under the terms of section 70 of the Crimes Act 1914, I could be liable to imprisonment for up to two years. The letter then went on with an excellent presentation of the conservative case for the preservation of cabinet secrecy. 
In passing, I would say that the thirty year rule applying to cabinet minutes and documents is an absurd rule at least in relation to domestic issues. Different considerations are involved in matters of foreign policy, security and intelligence. But for domestic matters the thirty year prohibition is simply a ban on knowledge and a severe handicap for serious scholars. Needless to say the fifty-year ban now placed on the cabinet notebooks, which record the cabinet discussions, is even more nonsensical. A Cabinet Diary records how this ban was put in place - it was a measure of the first Keating Government. A strong posse of cabinet ministers, backed by influential public servants, favoured burning the notebooks and they were only saved from the bonfire by a compromise that agreed to keep them from the public for fifty years.

Censorship, particularly of cabinet diaries, is the first constraint on keeping the two commandments. The second is length. Political diaries tend to be rather long documents. Those of Benn and Crossman run to several volumes. It is doubtful whether we have the market in Australia for such lengthy works. The tolerance of publishers again renders difficult the honouring of the two commandments.

Thirdly, editors of diaries become impatient with the state of the prose. Scribbling things down late at night or tiredly talking into a tape recorder do not produce limpid prose of the order of John Button's. So there is inevitably a problem of style suitable for publication. Fourthly, political diaries are more likely than other political writings to reduce a publisher's lawyers to apoplexy.

In the case of $A$ Cabinet Diary how did we handle these constraints yet remain faithful to the two commandments?

On the wisdom of publication, given the letter from the Department of the Prime Minister and Cabinet, we relied on a generous interpretation of Lord Widgery's judgment in the Crossman case. It was Widgery's view, at least as regards domestic matters, that ten years and three elections was a sufficient time lapse to allow the publication of the Crossman diaries without any injury to the constitutional system. As thirty years had passed since the Widgery judgment and decisions had become more liberal we considered that six years and three elections were sufficient. I survived.

I did excise a few sensitive foreign policy and intelligence references, though there is a description of a Cabinet discussion of an intelligence fiasco. I do not think that these conventions should be used to shield the intelligence services from scrutiny of incompetence, provided, of course, that any revelations do not damage national security or endanger particular individuals.

On the length of the manuscript, the publishers required a reduction of 70,000 words from the original diary. How, then, do you remain true to the original diary? I resolved that there was a key theme dominating the diary and that was 
the first Keating Government's struggle to survive. Much material extraneous to that theme was cut. For example, a lot of constituency stuff was cut, a lot of parochial South Australian politics went, but all the material relating to the central theme was virtually untouched in substance.

Pruning the prose made it, hopefully, more lucid, but I tried to avoid any change in substance, tone or judgments. I did restructure the Cabinet discussions to make them easier for readers to follow but at the same time sought to remain true to the arguments advanced by the ministers. Finally, given the concerns of the libel lawyers, I modified a few intemperate remarks about senior colleagues and excised about a dozen candid comments on minor figures. 